\title{
THE USE OF FOLKLORE AS A SIGN OF ETHNIC IDENTIFICATION IN TOURISM
}

\author{
Radost IVANOVA \\ Ethnographical Institute and Museum, 1000 Sofia, Moskovska 6A, Bulgaria
}

The past World Football Championship held recently in the U.S.A. has for the first time brought surprising success to Bulgaria - several victories of the national team over world famous football teams and the fourth place in the ranking. This has been quite a boost to the self-confidence of the Bulgarian people, who had until not long ago been notorious worldwide as umbrella assassins, as involved in an attempt against the life of the Pope and similar unproven accusations. In the euphoria of the victory, the Bulgarian footballers were declared by their compatriots to be Bulgaria's best ambassadors abroad, Bulgaria's best politicians having succeeded in rallying the strongly polarized political parties and their supporters under the national flag. In the course of more than a month, almost the entire Bulgarian people identified with their national football team, with "the valiant Bulgarian men" who had brought in a victory, self-confidence and renown throughout the whole world.

This is just one example illustrating how at a certain point sport can turn into a sign of ethnic identification. But just for a moment. Because what would happen should our team lose at the next football championship?

No doubt, each people has its peak moments, which outline its history and give it the self-confidence of a people. It also has characteristics, which are lastingly inherent in the people, with which they constantly identify, and which make them different from other peoples. Folklore has a leading role to play in this respect.

I shall deal more specifically with the use of folklore as a sign of ethnic identification in tourism; this is a case when a form of bringing out what is different, what is original and attractive is deliberately sought. Regrettably, Bulgaria has no particularly rich experience in this respect, lacking the fame of the countries with long established traditions in tourism like Italy, France, Spain, and Greece. It is only since the 1970s that the country's development as a tourist centre has been discussed more extensively. What is more, owing to the specificity of the political administration and economic management, group tourism tended to be developed with priority until not very long ago. Various forms of folklore were also harnessed to serve its purposes aimed at committing the foreign tourists not only to Bulgaria's natural scenery but also to the originality of Bulgarian culture and art.

The folklore used for the needs of tourism cannot be regarded a direct descendant of the classical folkloric tradition. What is meant here is not authentic folklore 
but a specific adaptation to a new cultural situation. This is one of the forms of folklorism taking shape within the frameworks of the amateur artistic activities, making particularly rapid progress in Bulgaria since the Second World War.

The adaptation of folklore to serve the purposes of tourism also depends on the specificity of the tourist centre itself. The Black Sea coast, for instance, which has developed as the main centre attracting foreign tourists, offers certain conditions, while Bulgaria's mountain resorts offer other conditions. What have been referred to as "folk-style restaurants" have been established in the best known seaside resorts like Zlatni Pyassatsi (Golden Sands), Slunchev Bryag (Sunny Beach), Albena and some others. They have matching names: Bulgarska Svatba (Bulgarian Wedding), Koukeri (Masked Dancers), Nestinarka (Fire Dancer), Trifon Zarezan (Trifon, the Vine Grower), Kosharite (The Sheepfold) and the like. Folk shows are performed in them each evening, whereby the contents of these shows in many cases correspond to the names of the restaurants. In the Bulgarska Svatba Restaurant in the St.St. Constantine and Helena Resort (not far from Varna), the folk show is a stylized musical and dance variant of the traditional Bulgarian wedding. The key elements of the wedding are included accompanied by songs, music and chain dances. The traditional distribution of presents at the end is also obligatory. The "bride" presents to the guests souvenir napkins, specially prepared for this purpose. The show of another restaurant - the Koukeri Masked Dancers, for instance, focusses on the dance of the Koukeri; in the Nestinarka Restaurant the attraction is the fire dance, and so on.

The artists of the folk shows are most often sought out and employed from among the members of the amateur artistic companies. They are booked only for the summer season. This usually takes place at the regional gatherings of folk song and dance groups or at the national folk song and dance festival in Koprivshtitsa, held once in five years. The rest of the year the folk singers and dancers go back home, where they engage in other activities and employment.

Somewhat different is the situation in Bulgaria's mountain resorts like Borovets, Pamporovo, Bansko and Koprivshtitsa, to mention but a few, which are not so well known abroad as the seaside resorts. They also offer folklore shows in some of their restaurants but conditions in the mountain make it possible also to include in the programme some more comprehensively conceived events, like for instance, a picnic, the reproduction of scenes using plots of folk songs and legends, the playacting of events from Bulgaria's history or even the attendance of some authentic rituals. For instance tourists visiting Koprivshtitsa in March may watch the rituals on the Feast Day of St. Theodore, when the horse races are the most attractive. On May 2, scenes from the April 1876 Uprising against Ottoman domination are reproduced there. In Bansko and in Koprivshtitsa picnics are most often organized, with a plot often encountered in the Bulgarian haidouk folklore. That is why in some cases the entertainment already begins on the way to the picnic. In Bansko for example the members of the ensemble, dressed up in haidouk attire and headed by a mounted voivode, perform an attack on the travellers. The voivode fires his gun, the haidouk company blocks the carts' path, and a few people playact an abduction of a maiden 
from among the group of tourists. Then the voivode welcomes the guests and they ride together in the horse-drawn carts until they reach the forest clearing where the music and dance show begins. No matter how "genuine" the scenario may seem, it is certainly not an organic part of traditional regional culture because each of the elements mentioned has been taken out of the cultural context of its functioning and placed in collision with the contemporary situation. In this situation, the elements of tradition lose or modify their original meaning. In the new situation they form a new entity based on new links and interrelationships. In this way, the scenario in its entirety claims to give an idea of Bulgarian hospitality sui generis. The success of the show depends not only on which and how many traditional elements have been included, but on whether the hosts manage to establish points of contact between their own culture and the culture of the foreign guests. The key to covering the distance between cultures is the entertaining show on the mountain clearing during and after the lunch. Here the performers manifest not only their playing, singing, and dancing talents (or skills), but also their abilities to improvise and present their art in a form which is understandable to the unaccustomed eyes and ears of the foreigners. They are helped in this by the extent to which their guests are open to the world: if they are curious to know about the country they are visiting, the distance between the cultures will not shock or repulse them.

The performing abilities of the musicians are of major importance in bridging the gap between hosts and guests. Generally speaking, their skill to manipulate the presentation of their own art of singing, playing, and dancing is at the core of their success. In this sense a good example is the folk song and dance show from the picnic in the town of Bansko. The program of the show consists exclusively of local songs and instrumental pieces. These items are almost never presented in their authentic version, because the unaccustomed audience would find them difficult to appreciate. What is more, the performers do not prefer the authentic version either. That is why the songs and melodies of the region, which are slow and trailing, are presented in a faster tempo, especially if the group of tourists comes from Spain and has preferences for a livelier tempo. The performers even search deliberately for the proper approach to the audience, taking into account its capacities for appreciation. If the foreign guests are folklore fans, this encourages the ensemble to present the authentic versions of the melodies. For the same reasons the ensemble also performs, though seldom, songs and instrumental pieces from other parts of the country as well as Serbian and Macedonian melodies they hear over the radio. This is a natural means of diversification, although the performers themselves consider it unjustifiable to use other songs in the presence of such a wealth of the local singing traditions. Their extremely rich repertoire gives them great possibilities to choose and diversify, and thus meet the interests of their audience. In this way, the performers themselves never get bored. Their desire, moreover, to continuously enrich their repertoire has stirred them to search for old songs and melodies known by very few people in the town.

The dances which are presented at the end of the lunch give greater opportunities for direct contacts. This stage of the show is designed to involve the viewers in 
the dances. Dances and games of greater attraction as spectacles, and of greater vivacity, are deliberately chosen. Worth noting, in my view, is the adaptation of a wedding ritual dance performed after song "How Black Pepper is Ground". This dance is not part of the traditional wedding in Bansko. The ensemble have learned it from another orchestra playing at weddings and have included it in their repertoire to diversify the show, hoping its funny movements and figures would allure the guests into joining in the dance. This wedding dance used to be performed during the first wedding night or after it and has strong erotic implications: the movements and gestures following the instructions of the lyrics symbolize sexual intercourse. It turned out, however, that the members of the ensemble did not even suspect the erotic meaning of the dance which, once taken out of context of the traditional wedding, had become pleasant entertainment arousing laughter.

Dances more often than songs and instrumental pieces are also included which are alien to the local, as well as to the Bulgarian tradition in general. This is especially true when the items are chosen for tourist groups for whom the transition from spectators to participants proves to be more difficult. For them, widely popular foreign dances and games are included in the program. These comprise for instance, the Romanian perenitsa, the dance known to Bulgarian performers as laurenci.

There is no doubt whatsoever that in all their diversity and variability the folk song and dance shows have a definite place and significance in the development of international tourism in Bulgaria. Essentially, they constitute a new type of folklorism. As this has become clear, this kind of folklorism has been the offspring of new cultural relations. It is a specific adaptation of folklore which makes use of the achievements of amateur artists and especially of popular wedding orchestras but does not fully coincide with them.

A typical feature of tourist folklorism is the endeavour to make the visitors sense the atmosphere of traditional regional folk culture without, however, admitting them to its innermost essence. This is achieved by taking elements of the classical tradition and combining them as a whole, in a kind of a ritual which has no counterpart in folk tradition, but it carries its spirit in most general terms. The character of that entity is modified for each performance and depends on the requirements of the guests and the improvisational skills of the hosts.

In the selection of elements, special emphasis is laid on their potential for making a good spectacle and a fine entertainment show. That is why the greatest attention is paid to the music and dance show. On the one hand, it presents folklore pieces that the guests hear or see for the first time. On the other hand, the reception offered the guests is not only a spectacle, but also a joint experience, participation in a common feast and in merrymaking, contributing to the strengthening of mutual confidence and cultural understanding.

In recent years the development of individual tourism, alongside the groups of tourists, makes businessmen turn more and more often to Bulgarian folklore tradition. The lovely natural scenery and the unique folklore tradition are the most appropriate combination bringing out the Bulgarian spirit and values which are yet to be presented to the world at large. 